International Research Journal of Management, IT \& Social Sciences
Available online at https://ijcujournals.us/journals/index.php/irjmis
Vol. 6 No. 1, January 2019, pages: 8 18
ISSN: 2395-7492
https://doi.org/10.21744/irjmis.v6n1.431

\title{
Company Area within Effectiveness of Accounting Information System
}

Komang Adisanjaya ${ }^{a}$ I Wayan Ramantha ${ }^{\mathrm{b}}$

Article history:

Received: 9 July 2018

Accepted: 30 November 2018

Published: 4 December 2018

\section{Keywords:}

accounting effectiveness; AIS formalization development; information system; support from top management; technology use;

\begin{abstract}
This study was about to test and gather the empirical proof about the impact of support from top management, personal ability, AIS formalization development, training, user involvement, and the use of technology to the effectiveness of accounting information system in the mini market of Singaraja city. This study used primary data as the source of data in which the data was quantitative data which was collected by using questionnaire by the staff of the mini market. The data were analyzed by using multiple regression approach. The result showed that the support of top management, personal ability, training, user involvement and the use of technology had positive significant on the effectiveness of accounting information system, then the AIS formalization development had no impact on the effectiveness of accounting information system.
\end{abstract}

2395-7492@ Copyright 2019. The Author. Published by SLOAP. This is an open-access article under the CC-BY-SA license (https://creativecommons.org/licenses/by/4.0/) All rights reserved.

\section{Author correspondence:}

Komang Adisanjaya,

A college student in the master of accounting at the faculty of economics and business, Universitas Udayana (UNUD)

Email address: komangadisanjaya94@gmail.com

\section{Introduction}

A company was an organization founded by someone or a group of people or other bodies whose activities carried out production and distribution to meet the economic needs of humans. Production and distribution activities were carried out by combining various factors of production, namely human, nature and capital. Companies depended on relevant information to maintain their competitiveness. The business presented was very useful for information users, namely external parties, such as customers, suppliers, stakeholders, and internal parties. The quality of information depended on three things, namely information must be accurate, timely and relevant. The main function of the Accounting Information System (AIS), which was processing data from financial transactions into useful information for the company (Tokic et.al., 2011; Dewi et al., 2018). Samuel (2013) stated that AIS had an important role to do effective decision making to control and organize the company activities to reach a better performance.

\footnotetext{
a Universitas Udayana, Denpasar, Indonesia

${ }^{\mathrm{b}}$ Universitas Udayana, Denpasar, Indonesia
} 
Onaolapo (2012), stated that the company effectivity depended on AIS. Effective AIS was a system which had the capability to produce a good quality information based on the purpose of the company itself. According to Soegiharto (2001) and Jen (2002), the effectivity of accounting information system in one company was based on two elements such as the internal and external environment. Internal environment were factors that originate from within the organization where the accounting information system was used or developed and indicates all possibilities that can affect the system. While the external environment was the factors that originate from outside or the environment in which the accounting information system was used or developed. In this study, the internal environment was divided into support from top management, AIS formalization development, and training. In contrast, the external environment was personal ability, user involvement and the use of technology.

By looking at the existing situation, the development of an effective accounting information system is certainly needed in the management of today's micro and macro businesses, including the mini market in it. The mini market arises because of human needs and increasing economic development. The mini market is a type of modern retail that is most aggressive in increasing the number of outlets and implementing a franchise system to increase the number of their outlets. The aim is to enlarge the business scale (so that it competes with the scale of the supermarket and hypermarket businesses), which in turn strengthens their bargaining position to suppliers.

However, there were many similar markets considered to be a competitor of the mini market in the village which had a similar quality and service compared to mini market such as the price was affordable and the service was good by using sophisticated accounting information system. Based on surveys and facts in the field, especially in Singaraja city, there were many mini markets which were franchised and independent, such as Alfamart Ngurah Rai, Alfamart Sudirman, Alfamart A. Yani, Alfamart Mayor Metra, Indomaret Udayana, Indomaret Mayor Metra, Bali Mardana mini market, Wista mini market, Cahaya Baru mini market, Elita mini market, etc. They were quite threatening to other traders, especially conventional traders, especially with similar companies, accounting information system technology that they used in their companies was also very sophisticated. Therefore, it was mandatory for every mini market in Singaraja city to own and used SIA technology. This was also supported by the statement of several traders in the city center, namely Ahmad Yani Street, as reported by Tribun Bali on October 14th, 2015, which said that the stall was always quiet since the mini market began to emerge. Other problems arise when the technology applied in information systems accounting was not suitable or not utilized optimally by the system user, so the application of accounting information systems does not provide maximum benefits to the company. This research was a duplicated study of previous studies. There were six hypotheses developed in this study, namely:

$\mathrm{H}_{1}$ : support from top management has a positive effect on the effectiveness of the accounting information system

$\mathrm{H}_{2}$ : personal ability has a positive effect on the effectiveness of the accounting information system

$\mathrm{H}_{3}$ : AIS formalization development has a positive effect on the effectiveness of the accounting information system

$\mathrm{H}_{4}$ : training has a positive effect on the effectiveness of the accounting information system

$\mathrm{H}_{5}$ : user involvement has a positive effect on the effectiveness of the accounting information system

$\mathrm{H}_{6}$ : the use of technology has a positive effect on the effectiveness of the accounting information system.

\section{Materials and Methods}

The concept of this research was figured like this figure 1:

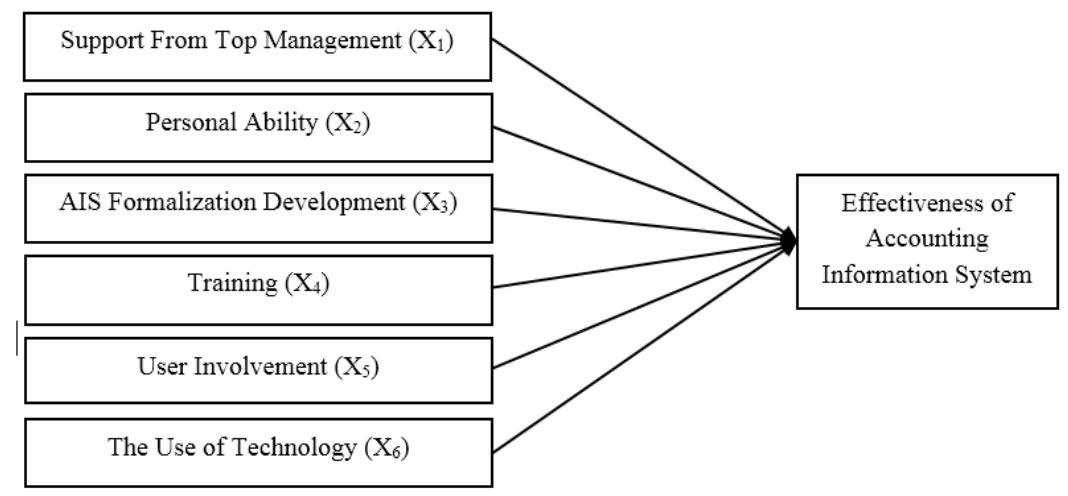

Figure 1. Concept research

Adisanjaya, K., \& Ramantha, I. W. (2018). Company area within effectiveness of accounting information system. International Research Journal of Management, IT and Social Sciences, 6(1), 8-18. https://doi.org/10.21744/irjmis.v6n1.431 
This type of research used explanatory research, namely causality explained a relationship between variables through testing hypotheses (Ghozali, 2006). The type of data used is quantitative data. The data used in this study based on the source was primary data. The method of data collection used was the survey method, namely the questionnaire technique. The population taken in this study were mini market employees from 15 companies in the city of Singaraja. The nonprobability sampling method used in this study was purposive sampling technique, namely the technique of determining samples with certain considerations (Sugiyono, 2008). The sample determination criteria in this study were based on mini markets that are independent or privately owned, using AIS technology in their operations and the availability of data. Thus, the sample in this study was based on criteria, namely 4 companies with 79 samples. Independent variables in this study supported from top management, personal ability, AIS formalization development, training, user involvement, and the use of technology while the dependent variable is the effectiveness of accounting information systems. Data analysis in this study used the SPSS program assistance (Statistical Package for the Social Sciences version 19). The data analysis techniques used in this study such as validity and reliability tests, descriptive statistical tests, classic assumption tests, and multiple linear regression tests.

\section{Results and Discussions}

The brief description in this study could be seen in table 1:

Table 1

Descriptive statistics test results

\begin{tabular}{llllll}
\hline \multirow{2}{*}{ Variable } & \multicolumn{5}{c}{ Statistics } \\
\cline { 2 - 6 } & Mean & Median & Standard Deviation & Minimum & Maximum \\
\hline $\mathrm{X}_{1}$ & 20,41 & 20,00 & 2,16 & 16 & 25 \\
$\mathrm{X}_{2}$ & 51,46 & 51,00 & 4,85 & 36 & 60 \\
$\mathrm{X}_{3}$ & 22,59 & 23,00 & 1,89 & 19 & 25 \\
$\mathrm{X}_{4}$ & 20,24 & 21,00 & 2,81 & 15 & 25 \\
$\mathrm{X}_{5}$ & 8,73 & 9,00 & 1,21 & 6 & 10 \\
$\mathrm{X}_{6}$ & 35,38 & 35,00 & 2,67 & 29 & 40 \\
$\mathrm{Y}$ & 20,78 & 20,00 & 1,95 & 15 & 25 \\
\hline
\end{tabular}

Information: $\mathrm{X}_{1}$ is support from top management, $\mathrm{X}_{2}$ is personal ability, $\mathrm{X}_{3}$ is $\mathrm{AIS}$ formalization development, $\mathrm{X}_{4}$ is training, $\mathrm{X}_{5}$ is user involvement, $\mathrm{X}_{6}$ is the use of technology, and $\mathrm{Y}$ is the effectiveness of accounting information system. Based on table 1, it showed that all standard deviations of the research variable had a value which was smaller than the average value, because of that it could be said that the respondent's response to the research variable did not vary.

Table 2

Instrument validity test results

\begin{tabular}{ccccc}
\hline No. & Variable/ Statement & Pearson Colleration & Sig. (2-tailed) & Information \\
\hline \multicolumn{2}{c}{ Support From Top Management $\left(\mathrm{X}_{1}\right)$} & & & \\
\hline 1 & $\mathrm{X}_{1.1}$ & 0,738 & 0,000 & Valid \\
2 & $\mathrm{X}_{1.2}$ & 0,765 & 0,000 & Valid \\
3 & $\mathrm{X}_{1.3}$ & 0,591 & 0,000 & Valid \\
4 & $\mathrm{X}_{1.4}$ & 0,699 & 0,000 & Valid \\
5 & $\mathrm{X}_{1.5}$ & 0,719 & 0,000 & Valid \\
\hline \multicolumn{2}{l}{ Personal Ability $\left(\mathrm{X}_{2}\right)$} & & & \\
\hline \multicolumn{1}{l}{$\mathrm{X}_{2.1}$} & $\mathrm{X}_{2.2}$ & 0,760 & 0,000 & Valid \\
3 & $\mathrm{X}_{2.3}$ & 0,695 & 0,000 & Valid \\
4 & $\mathrm{X}_{2.4}$ & 0,628 & 0,000 & Valid \\
5 & $\mathrm{X}_{2.5}$ & 0,686 & 0,000 & Valid \\
\end{tabular}




\begin{tabular}{|c|c|c|c|c|}
\hline 6 & $\mathrm{X}_{2.6}$ & 0,755 & 0,000 & Valid \\
\hline 7 & $\mathrm{X}_{2.7}$ & 0,623 & 0,000 & Valid \\
\hline 8 & $\mathrm{X}_{2.8}$ & 0,584 & 0,000 & Valid \\
\hline 9 & $\mathrm{X}_{2.9}$ & 0,690 & 0,000 & Valid \\
\hline 10 & $\mathrm{X}_{2.10}$ & 0,763 & 0,000 & Valid \\
\hline 11 & $\mathrm{X}_{2.11}$ & 0,730 & 0,000 & Valid \\
\hline 12 & $\mathrm{X}_{2.12}$ & 0,660 & 0,000 & Valid \\
\hline \multicolumn{5}{|c|}{ AIS Formalization Development $\left(\mathrm{X}_{3}\right)$} \\
\hline 1 & $\mathrm{X}_{3.1}$ & 0,643 & 0,000 & Valid \\
\hline 2 & $\mathrm{X}_{3.2}$ & 0,586 & 0,000 & Valid \\
\hline 3 & $\mathrm{X}_{3.3}$ & 0,727 & 0,000 & Valid \\
\hline 4 & $\mathrm{X}_{3.4}$ & 0,791 & 0,000 & Valid \\
\hline 5 & $\mathrm{X}_{3.5}$ & 0,772 & 0,000 & Valid \\
\hline \multicolumn{5}{|c|}{ Training $\left(\mathrm{X}_{4}\right)$} \\
\hline 1 & $\mathrm{X}_{4.1}$ & 0,808 & 0,000 & Valid \\
\hline 2 & $\mathrm{X}_{4.2}$ & 0,845 & 0,000 & Valid \\
\hline 3 & $\mathrm{X}_{4.3}$ & 0,833 & 0,000 & Valid \\
\hline 4 & $\mathrm{X}_{4.4}$ & 0,816 & 0,000 & Valid \\
\hline 5 & $\mathrm{X}_{4.5}$ & 0,771 & 0,000 & Valid \\
\hline \multicolumn{5}{|c|}{ User Involvement $\left(\mathrm{X}_{5}\right)$} \\
\hline 1 & $\mathrm{X}_{5.1}$ & 0,898 & 0,000 & Valid \\
\hline 2 & $\mathrm{X}_{5.2}$ & 0,893 & 0,000 & Valid \\
\hline \multicolumn{5}{|c|}{ The Use of Technology $\left(\mathrm{X}_{6}\right)$} \\
\hline 1 & $\mathrm{X}_{6.1}$ & 0,391 & 0,000 & Valid \\
\hline 2 & $X_{6.2}$ & 0,732 & 0,000 & Valid \\
\hline 3 & $\mathrm{X}_{6.3}$ & 0,576 & 0,000 & Valid \\
\hline 4 & $\mathrm{X}_{6.4}$ & 0,549 & 0,000 & Valid \\
\hline 5 & $\mathrm{X}_{6.5}$ & 0,561 & 0,000 & Valid \\
\hline 6 & $\mathrm{X}_{6.6}$ & 0,611 & 0,000 & Valid \\
\hline 7 & $\mathrm{X}_{6.7}$ & 0,666 & 0,000 & Valid \\
\hline 8 & $\mathrm{X}_{6.8}$ & 0,648 & 0,000 & Valid \\
\hline \multicolumn{5}{|c|}{ The effectiveness of Accounting Information System (Y) } \\
\hline 1 & $\mathrm{Y}_{1}$ & 0,729 & 0,000 & Valid \\
\hline 2 & $\mathrm{Y}_{2}$ & 0,757 & 0,000 & Valid \\
\hline 3 & $\mathrm{Y}_{3}$ & 0,661 & 0,000 & Valid \\
\hline 4 & $\mathrm{Y}_{4}$ & 0,560 & 0,000 & Valid \\
\hline 5 & $\mathrm{Y}_{5}$ & 0,720 & 0,000 & Valid \\
\hline
\end{tabular}

Table 3

Instrument reliability test results

\begin{tabular}{|c|c|c|c|}
\hline No. & Variable & Koefficient Alpha Cronbach & Informatian \\
\hline 1 & Support From Top Management $\left(\mathrm{X}_{1}\right)$ & 0,740 & Reliable \\
\hline 2 & Personal Ability $\left(\mathrm{X}_{2}\right)$ & 0,899 & Reliable \\
\hline 3 & AIS Formalization Development $\left(\mathrm{X}_{3}\right)$ & 0,747 & Reliable \\
\hline 4 & Training $\left(\mathrm{X}_{4}\right)$ & 0,873 & Reliable \\
\hline 5 & User Involvement $\left(\mathrm{X}_{5}\right)$ & 0,754 & Reliable \\
\hline 6 & The Use of Technology $\left(X_{6}\right)$ & 0,738 & Reliable \\
\hline 7 & Effectiveness of Accounting Information System (Y) & 0,717 & Reliable \\
\hline
\end{tabular}

In terms of data quality result, table 2 showed that value of Sig. (2-tailed) the correlation for all items was smaller than 0.05 which meant all statement items were declared valid. Table 3 showed all variables had Cronbach Alpha which was greater than 0.60 . Because of that, it could be concluded that all research instruments were reliable.

Adisanjaya, K., \& Ramantha, I. W. (2018). Company area within effectiveness of accounting information system. International Research Journal of Management, IT and Social Sciences, 6(1), 8-18. https://doi.org/10.21744/irjmis.v6n1.431 
Table 4

Data normality test results

\begin{tabular}{lll}
\hline \multicolumn{3}{c}{ One-Sample Kolgomorov-Smirnov Test } \\
\hline $\mathrm{N}$ & & Unstandardized Residual \\
\hline Normal Parameters ${ }^{a, b}$ & Mean & \\
& Std, Deviation & 0,000 \\
\hline Most Extreme Differences & Absolute & 0,721 \\
& Positive & 0,059 \\
& Negative & 0,059 \\
\hline Kolmogorov-Smirnov $Z$ & & $-0,040$ \\
Asymp. Sig. (2-tailed) & & 0,527 \\
\hline
\end{tabular}

Table 5

Multicollinearity test results

\begin{tabular}{lcc}
\hline \multirow{2}{*}{ Model } & \multicolumn{2}{c}{ Collinearity Statistics } \\
\cline { 2 - 3 } & Tolerance & VIF \\
\hline Constant) & & 3,383 \\
Support From Top Management $\left(\mathrm{X}_{1}\right)$ & 0,296 & 1,668 \\
Personal Ability $\left(\mathrm{X}_{2}\right)$ & 0,599 & 2,081 \\
AIS Formalization Development $\left(\mathrm{X}_{3}\right)$ & 0,480 & 4,651 \\
Training $\left(\mathrm{X}_{4}\right)$ & 0,215 & 3,227 \\
User Involvement $\left(\mathrm{X}_{5}\right)$ & 0,310 & 6,793 \\
The Use of Technology $\left(\mathrm{X}_{6}\right)$ & 0,147 & \\
\hline
\end{tabular}

Table 6

Heteroscedasticity test results

\begin{tabular}{cllllll}
\hline \multirow{2}{*}{ Model } & & \multicolumn{2}{c}{ Unstandardized Coefficients } & Standardized Coefficients & & \multirow{2}{*}{ Sig. } \\
\cline { 3 - 5 } & & $B$ & Std. Error & Beta & 2,032 & 0,046 \\
\cline { 3 - 5 } 1 & (Constant) & 1,954 & 0,962 & & 1,144 & 0,257 \\
& $\mathrm{X}_{1}$ & 0,049 & 0,043 & 0,237 & 0,552 & 0,583 \\
& $\mathrm{X}_{2}$ & 0,007 & 0,013 & 0,080 & $-1,570$ & 0,121 \\
& $\mathrm{X}_{3}$ & $-0,060$ & 0,038 & $-0,255$ & 1,458 & 0,149 \\
& $\mathrm{X}_{4}$ & 0,056 & 0,039 & 0,354 & 1,295 & 0,199 \\
& $\mathrm{X}_{5}$ & 0,097 & 0,075 & 0,262 & $-1,956$ & 0,054 \\
\hline
\end{tabular}

For the classic assumption test, table 4 the normality test showed that the value of Asymp. Sig. (2-tailed) of 0.944. Value of Asymp. Sig. (2-tailed) greater than 0.05 for the One-Sample Kolmogorov-Smirnov statistic, it indicated that the distribution of data was normally distributed. Table 5 of the multicollinearity test shows the VIF value of each independent variable was smaller than 10 and the tolerance value was greater than 0.1 , thus it could be concluded that among the independent variables there was no correlation or there was no multicollinearity in the regression model. Table 6 heteroscedasticity test showed that the significance value between the independent variables with absolute residuals was all greater than 0.05 . Because of that, it could be concluded that there was no problem with heteroscedasticity in the regression model. Testing the hypothesis in this study was carried out quantitatively based on respondents answers to the items in the research questionnaire. The data analysis technique used in this study was multiple regression analysis. By using illustration, the results of multiple regression tests in this study appeared as in table 7, table 8, and table 9 below: 
Table 7

Partial multiple linear regression analysis

\begin{tabular}{lllllll}
\hline \multirow{2}{*}{ Model } & \multicolumn{2}{c}{ Unstandardized Coefficients } & Standardized Coefficients & \multirow{2}{*}{$\mathrm{t}$} & \multirow{2}{*}{ Sig. } \\
\cline { 3 - 6 } & $\mathrm{B}$ & Std. Error & Beta & 1,032 & 0,306 \\
& $($ Constant $)$ & 1,675 & 1,623 & & 2,570 & 0,012 \\
& $\mathrm{X}_{1}$ & 0,186 & 0,072 & 0,207 & 2,704 & 0,009 \\
& $\mathrm{X}_{2}$ & 0,061 & 0,023 & 0,153 & $-1,398$ & 0,166 \\
& $\mathrm{X}_{3}$ & $-0,091$ & 0,065 & $-0,088$ & 2,254 & 0,027 \\
& $\mathrm{X}_{4}$ & 0,147 & 0,065 & 0,212 & 3,171 & 0,002 \\
& $\mathrm{X}_{5}$ & 0,402 & 0,127 & 0,249 & 2,635 & 0,010 \\
\hline & $\mathrm{X}_{6}$ & 0,219 & 0,083 & 0,300 &
\end{tabular}

Information: $\mathrm{X}_{1}$ is support from top management, $\mathrm{X}_{2}$ is personal ability, $\mathrm{X}_{3}$ is AIS formalization development, $\mathrm{X}_{4}$ is training, $\mathrm{X}_{5}$ is user involvement, $\mathrm{X}_{6}$ is the use of technology, and $\mathrm{Y}$ is the effectiveness of accounting information system.

Table 8

Simultaneous multiple linear regression analysis

\begin{tabular}{lllllll}
\hline Model & & Sum of Squares & $d f$ & Mean Square & F & Sig. \\
\hline 1 & Regression & 254,754 & 6 & 42,459 & 75,319 & 0,000 \\
& Residual & 40,588 & 72 & 0,564 & & \\
& Total & 295,342 & 78 & & & \\
\hline
\end{tabular}

Table 9

Determination coefficient analysis

\begin{tabular}{lllll}
\hline \multicolumn{5}{c}{ Model Summary } \\
\hline Model & $\mathrm{R}$ & $\mathrm{R}$ Square & Adjusted $\mathrm{R}$ Square & Std. Error of the Estimate \\
\hline 1 & 0,929 & 0,863 & 0,851 & 0,751 \\
\hline
\end{tabular}

Based on table 7, it could be analyzed that the top management support variable had a significance value of 0.012 , personal ability had a significance value of 0.009 , formalization of AIS development had a significance value of 0.166 , training had a significance value of 0.027 , user involvement had a significance value of 0.002 , and the use of technology had a significance value of 0.010. Thus, top management support, personal ability, training, user involvement, and the use of technology partially had a positive effect on the effectiveness of accounting information systems. While the formalization of the development of AIS partially had no effect on the effectiveness of accounting information systems.

Based on table 8 , the calculated F value was 75.319 with a significance value of 0.000 . Significance value 0,000 $<0,05$, then the decision simultaneously there was an influence between top management support, personal ability, formalization of AIS development, training, user involvement, and the use of technology on the effectiveness of accounting information systems.

Based on table 9, it was known that the calculation of the determination coefficient was 0.851 . It showed that $85.1 \%$ of the effectiveness of the accounting information system was influenced by top management support, personal ability, formalization of AIS development, training, user involvement, and the use of technology while the remaining $14.9 \%$ was influenced by other factors.

\subsection{The effect of support from top management on the effectiveness of the accounting information system}

H1 was accepted. Then, there was a significant effect of top management support on the effectiveness of the accounting information system, which was indicated by a significant probability value of 0.012 smaller than 0.05 . According to Ihsan \& Ishak (2005), top management support was an important factor in determining the effectiveness

Adisanjaya, K., \& Ramantha, I. W. (2018). Company area within effectiveness of accounting information system. International Research Journal of Management, IT and Social Sciences, 6(1), 8-18. https://doi.org/10.21744/irjmis.v6n1.431 
of information system acceptance in organizations. Al-Ibbini (2017), also stated that top management support was one of the variables that affect the performance of an efficient, effective, and integrated accounting information system. The results of this study were not consistent with the results of previous studies conducted by Latifah (2007), while consistent with the results of previous research conducted by Al-Zwyalif (2012).

\subsection{The effect of personal ability on the effectiveness of the accounting information system}

$\mathrm{H} 2$ was accepted. Then, there was a significant effect of personal ability on the effectiveness of accounting information systems, which is indicated by a significant probability value of 0.009 smaller than 0.05 . Personal ability was very important in order to create an effective accounting information system. Where the longer the user used a system, it increased user satisfaction because it increased its ability to utilize existing information systems (Robbins, 2009). The results of this study were not consistent with the results of previous studies conducted by Luciana \& Irmaya (2008), while this study was consistent with the results of previous studies conducted by Choe (1996).

\subsection{The effect of AIS formalization development on the effectiveness of the accounting information system}

H3 was rejected. Then, there was no significant effect of formalization of AIS development on the effectiveness of accounting information systems, which was indicated by a significant probability value of 0.166 greater than 0.05 . It happened usually because system users, especially employees, were not satisfied with the formalization applied. In terms of cost, it was possible that what was planned and proclaimed was not what was realized by the company, the company could only provide a little funding for the development of an accounting information system. The results of this study were not consistent with the results of previous studies conducted by Hendra (2014), while consistent with the results of previous studies conducted by Prabowo et al., (2013).

\subsection{The effect of training on the effectiveness of the accounting information system}

H4 was accepted. Then, there was a significant effect of training on the effectiveness of the accounting information system, which was indicated by a significant probability value of 0.027 smaller than 0.05 . Abdallah (2013) recommended that personnel training in accounting information system harmonization must be done to support the effectiveness of accounting information systems were not consistent with the results of previous studies conducted by Komara (2005), while it consistent with the results of previous studies conducted by Al-Zwyalif (2012), Medina \& Y. Loera (2013).

\subsection{The effect of user involvement on the effectiveness of the accounting information system}

H5 was accepted. Then, there was a significant effect of user involvement on the effectiveness of accounting information systems, which was indicated by a significant probability value of 0.002 smaller than 0.05 . Hajiha \& Azizi (2011), stated that system user participation in information system development was an effective factor that influences information system performance which had an impact on the success of the information system. The results of this study were not consistent with the results of previous studies conducted by Bulutoding \& Antong (2014), while consistent with the results of previous studies conducted by Bano \& Didar (2013), Delone \& McLean (2003), and McKeen et al., (1994).

\subsection{The effect of the use of technology on the effectiveness of the accounting information system}

H6 was accepted. Then, there was a significant effect of the use of technology on the effectiveness of accounting information systems, which was indicated by a significant probability value of 0.010 smaller than 0.05 . Ghasemi and Vahid (2011) research also stated that the use of computerized accounting technology had provided opportunities for companies to perform more accounting information system functions effective and efficient because the use of computerization had brought significant time and cost savings. The results of this study were not consistent with the results of previous studies conducted by Khasanah (2012), while consistent with the research conducted by Belfo \& Antonio (2013). 


\section{Conclusion}

Based on the results of the research that had been conducted on the environmental influence of the company on the effectiveness accounting information system of the mini market in the city of Singaraja, it could be concluded that there was a positive and significant influence between the support of top management on the effectiveness of the accounting information system. There was a positive and significant influence between personal ability on the effectiveness of accounting information systems. There was no positive and significant influence between the AIS formalization development on the effectiveness of accounting information systems. There was a positive and significant influence between training on the effectiveness of accounting information systems. There was a positive and significant influence between user involvement on the effectiveness of accounting information systems. Last, there was a positive and significant influence between the use of technology on the effectiveness of accounting information systems.

From the results of this study, there were still various limitations that could be developed in subsequent research that wanted to analyze the effectiveness of accounting information systems, some of which were limitations in this study among others was this study still used multiple regression analysis and the sample from the study was small. Then some suggestions that can be conveyed are further researchers which are advised to develop research models such as moderation or mediation with more sophisticated analysis tools such as PLS. In addition, the number of samples needs to be added by expanding the research area so that the results of the study can be generalized. Data collection techniques need to be added with interviews or observations so that the level of accuracy of the data that will be processed and produced will be more relevant.

Conflict of interest statement and funding sources

The authors declared that they have no competing interest. The study was financed by independent funding.

Statement of authorship

The authors have a responsibility for the conception and design of the study. The authors have approved the final article.

\section{Acknowledgments}

The authors would like to thank the reviewer for their support, advice, and valuable time. Thank the editor of the journal for their consideration to review this article.

Adisanjaya, K., \& Ramantha, I. W. (2018). Company area within effectiveness of accounting information system. International Research Journal of Management, IT and Social Sciences, 6(1), 8-18. 


\section{References}

Abdallah, A. A. J. (2014). The impact of using accounting information systems on the quality of financial statements submitted to the Income and sales tax Department in Jordan. European Scientific Journal, ESJ, 9(10). http://dx.doi.org/10.19044/esj.2013.v9n10p\%25p

Al-Ibbini, O. A. M. (2017). The Critical Success Factors Influencing the Quality of Accounting Information Systems and the Expected Performance. International Journal of Economics and Finance, 9(12), 162.

Al-Zwyalif, I. M. (2012). Using Six Sigma Approach to Improve Accounting Information Systems Performance. European Journal of Economics, Finance and Administrative Sciences, 55.

Bano, M., \& Zowghi, D. (2013, April). User involvement in software development and system success: a systematic literature review. In Proceedings of the 17th International Conference on Evaluation and Assessment in Software Engineering (pp. 125-130). ACM. https://doi.org/10.1145/2460999.2461017

Belfo, F., \& Trigo, A. (2013). Accounting information systems: Tradition and future directions. Procedia Technology, 9, 536-546. https://doi.org/10.1016/j.protcy.2013.12.060

Bodnar, G. H., \& Hopwood, W. S. (2000). Sistem informasi akuntansi. Buku Satu, Salemba Empat, Jakarta.

Bulutoding, L., \& Amiruddin, A. (2016). Pengaruh Faktor Internal dan Eksternal Terhadap Kinerja Sistem Informasi: Studi Pada Perbankan. Jurnal Akuntansi dan Investasi, 15(2), 124-136.

Choe, J. M. (1996). The relationships among performance of accounting information systems, influence factors, and evolution level of information systems. Journal of Management Information Systems, 12(4), 215-239. https://doi.org/10.1080/07421222.1996.11518107

Darmawan, P. H. (2014). Analisis Pengaruh Keterlibatan Pemakai Dalam Pengembangan Sistem Informasi, Dukungan Manajemen Puncak, Dan Formalisasi Pengembangan Sistem Informasi Terhadap Kinerja Sistem Informasi Akuntansi Pada Pt. Bank Jateng Cabang Ungar. Skripsi, Fakultas Ekonomi \& Bisnis.

DeLone, W. H., \& McLean, E. R. (1992). Information systems success: The quest for the dependent variable. Information systems research, 3(1), 60-95. https://doi.org/10.1287/isre.3.1.60

Dewi, I. G. A. A. O., Dewi, I. G. A. A. P., Kustina, K. T., \& Prena, G. D. (2018). Culture of tri hita karana on ease of use perception and use of accounting information system. International Journal of Social Sciences and Humanities (IJSSH), 2(2), 77-86. https://doi.org/10.29332/ijssh.v2n2.131

Dewi, K. D. P., Purnamawati, I. G. A., \& Sinarwati, N. K. (2016). Pengaruh penggunaan teknologi informasi, partisipasi pemakai, ukuran organisasi, personal capability terhadap efektivitas sistem informasi akuntansi (Studi Empiris Pada Hotel yang Terletak di Kawasan Buleleng Barat). JIMAT (Jurnal Ilmiah Mahasiswa Akuntansi) Undiksha, 4(1).

Ferdianti, A. (2017). Analisis faktor-faktor yang mempengaruhi kinerja sistem informasi akuntansi (Pada Satuan Kerja Perangkat Daerah di Kabupaten Gunungkidul). Prodi Akuntansi UPY.

Ghasemi, M., Shafeiepour, V., Aslani, M., \& Barvayeh, E. (2011). The impact of Information Technology (IT) on modern accounting systems. Procedia-Social and Behavioral Sciences, 28, $112-116$. https://doi.org/10.1016/j.sbspro.2011.11.023

Ghozali, I. (2006). Aplikasi analisis multivariate dengan program SPSS. Badan Penerbit Universitas Diponegoro.

Hajiha, Z., \& Azizi, Z. A. P. (2011). Effective factors on alignment of accounting information systems in manufacturing companies: evidence from iran. Information Management and Business Review, 3(3), $158-170$.

Ikhsan, A., \& Ishak, M. (2005). Akuntansi Keperilakuan. Jakarta: salemba empat.

Khasanah, A. (2012). Analisis Faktor-Faktor yang Menentukan Efektivitas Sistem Informasi pada Organisasi Sektor Publik(Doctoral dissertation, Universitas Muhammadiyah Surakarta).

Komara, A. (2010). Analisis faktor-faktor yang mempengaruhi kinerja sistem informasi akuntansi. Jurnal Manajemen, Akuntansi \& Sistem Informasi, 6(2), 143-160.

Latifah, L., \& Sabeni, A. (2007). Faktor Keprilakuan Organisasi dalam Implementasi Sistem Akuntansi Keuangan Daerah (Studi Empiris Pada Pemerintah Kabupaten dan Kota di Jawa Tengah dan Daerah Istimewa Yogyakarta).

Luciana, S. \& Irmaya, B. (2008). Analisis Faktor-Faktor yang Mempengaruhi Kinerja Sistem Informasi Akuntansi pada Bank Umum Pemerintah di Wilayah Surabaya dan Sidoarjo (Skripsi, Surabaya: STIE. Perbanas).

McKeen, J. D., Guimaraes, T., \& Wetherbe, J. C. (1994). The relationship between user participation and user satisfaction: an investigation of four contingency factors. MIS quarterly, 427-451. https://doi.org/10.2307/249523

Medina, J. M., Loera, Y., González, K., \& Mora, A. (2013, January). Training Users of Accounting Information Systems for their Satisfaction, Decision-making, and Competitiveness. In Proceedings of the International Conference on Software Engineering Research and Practice (SERP) (p. 1). The Steering Committee of The World Congress in Computer Science, Computer Engineering and Applied Computing (WorldComp). 
Onaolapo, A. A., \& Odetayo, T. A. (2012). Effect of accounting information system on organisational effectiveness: a case study of selected construction companies in Ibadan, Nigeria. American Journal of Business and Management, 1(4), 183-189. https://doi.org/10.11634/216796061706210

Ratnaningsih, K. I., \& Suaryana, I. G. N. A. (2014). Pengaruh Kecanggihan Teknologi Informasi, Partisipasi Manajemen, dan Pengetahuan Manajer Akuntansi pada Efektivitas Sistem Informasi Akuntansi. E-Jurnal Akuntansi, 1-16.

Robbins, S. P., \& Judge, T. A. (2001). Organizational behavior.

Samuel, N. (2013). Impact of accounting information systems on organizational effectiveness of automobile companies in Kenya. Research Project.

Soegiharto, (2001). Influence factors affecting the performance of aaccounting information systems. Gajah Mada International Journal of Business.

Sugiyono, D. (2008). Metode Penelitian Bisnis. Bandung: Pusat Bahasa Depdiknas.

Tokic, M., Spanja, M., Tokic, I., \& Blazevic, I. (2011). Functional structure of entrepreneurial accounting information systems. Annals of the Faculty of Engineering Hunedoara, 9(2), 165.

Adisanjaya, K., \& Ramantha, I. W. (2018). Company area within effectiveness of accounting information system. International Research Journal of Management, IT and Social Sciences, 6(1), 8-18. https://doi.org/10.21744/irjmis.v6n1.431 


\section{Biography of Authors}

\begin{tabular}{|l|l|}
\hline Komang Adisanjaya, SE. is a college student in the master of accounting at the faculty of \\
economics and business, Universitas Udayana (UNUD University). He was born in \\
Gunungsari, October 26nd, 1994. He lives at Jl. Padang Kartika II No. 06 Padang Sambian, \\
Badung, Bali. He graduated his Bachelor in Accounting, Universitas Pendidikan Ganesha \\
(Undiksha University), Singaraja-Bali, Indonesia in 2017. He interested in financial statement \\
analysis, management accounting, and accounting information system. \\
Email: komangadisanjaya94@gmail.com \\
\hline \\
$\begin{array}{l}\text { Prof. Dr. I Wayan Ramantha, SE., MM. Ak., CPA. is a lecturer in the faculty of economics } \\
\text { and business, Universitas Udayana (UNUD University). He was born in Gianyar, May 10 } \\
\text { 1959. He lives at Banjar Tegaltamu, Batubulan, Gianyar, Bali. He graduated his Bachelor in } \\
\text { Accounting, Universitas Udayana (UNUD University), Denpasar-Bali, Indonesia in 1984. He } \\
\text { finished his Master of Management (M.M.), Udayana University (UNUD), Denpasar, Bali, } \\
\text { Indonesia in 2000. And he finished his doctorate (Dr.), Airlangga University, Surabaya, Jawa } \\
\text { Timur, Indonesia in 2004. He interested in financial management, business and professional } \\
\text { ethics, financial management, administration of management, entrepreneurship, financial } \\
\text { markets, and financial institutions. } \\
\text { Email: wayan.ramantha@ @ hotmail.com }\end{array}$ \\
\hline
\end{tabular}

